\title{
Use of personal protective equipment among waste workers of Sisdol landfill site of Nepal
}

\author{
Khanal A ${ }^{1}$, Sondhi $A^{1}$, Giri $\mathbf{S}^{2}$
}

${ }^{1}$ Department of Energy and Environment, TERI School of Advanced Studies, New Delhi, India, ${ }^{2} E n v i r o n m e n t$ Education and Sustainable Development, Kathmandu University School of Education, Lalitpur, Nepal

\section{ABSTRACT}

Introduction: Solid waste management is a major issue in Nepal with Kathmandu valley generating the highest amount of solid waste. After recovery, the solid waste generated in Kathmandu valley is transferred to the Sisdol landfill site. There are waste workers in Sisdol landfill site who sustain their livelihood by collecting recyclables from those wastes. Personal protective equipment (PPE) is necessary to protect the frontline waste workers against infection. In addition, the waste workers need to know the proper usage of PPE in order to protect themselves from contamination. This study aimed to assess the awareness and proper usage of PPE along with the challenges faced by the waste workers at Sisdol landfill site.

Methods: A descriptive cross-sectional study was conducted to collect data from landfill waste workers of Sisdol located at Kakani Rural Municipality in Nuwakot district of Nepal. A convenience sampling method was used based on the availability of landfill waste workers on that day and their willingness to participate. The data was collected using the structured questionnaire and personal interview of available waste workers.

Results: The study comprised of $65 \%$ female and $35 \%$ male waste workers. The highest percentage of waste workers belonged to $27-37$ years age group occupying $43 \%$ of total respondents. Around $92 \%$ waste workers had participated in any orientation/training or session related to PPE and its usage. About $60 \%$ landfill waste workers were found only using mask and gloves.

Conclusion: There is small number of waste workers who wish to wear full set of PPE. Most of them only like to wear mask and gloves. The gender, age group and the education level of waste workers had no association with the usage of PPE during the work.

Key words: Landfill, Nepal, Occupational Risks, Personal Protective Equipment, Sisdol, Waste Worker

\section{Introduction}

S olid waste management is a major issue in Nepal having unsanitary waste management and disposal practices. ${ }^{1,2}$ Most of the studies have identified rapid population growth, urbanization and

DOI: https://doi.org/10.3126/ijosh.v11i3.39768

Conflicts of interest: None

Supporting agencies: None

Date of submission: 20.05.2021

Date of acceptance: 11.08 .2021

Date of publication: 30.09 .2021

\section{Corresponding Author}

Mr. Ashish Khanal

PhD Student

Department of Energy and Environment

TERI School of Advanced Studies, New Delhi, India

Email: ashishkhanalk@yahoo.com

ORCID ID: 0000-0003-4175-977X poor management by municipalities as the major challenges for the effective solid waste management in Nepal. ${ }^{3-10}$ In 2017, the projected waste generation of Nepal was about 3023 tons per day with average per capita waste generation rate of $0.223 \mathrm{~kg} /$ person/day. ${ }^{1,9}$ Around $44 \%$ of municipal solid waste in Kathmandu valley are the reusable and recyclable materials. ${ }^{11}$

Kathmandu valley generates the highest amount of solid waste in Nepal with $87 \%$ waste collection rate. ${ }^{12}$ The solid waste management has become a major challenge for Kathmandu leading most of the collected waste being dumped at the landfill site. ${ }^{13}$ Due to inadequate collection services, the dumping of

\section{c) (i) (8)}

This journal is licensed under a Creative Commons AttributionNon Commercial 4.0 International License. 
waste in public place has become a common practice in Nepal. ${ }^{14}$ The waste collected from most areas of Kathmandu valley are transferred to Sisdol landfill site located in Nuwakot district. Landfill waste workers are poor and marginalized and sustain their livelihood by collecting recyclables. ${ }^{15,16}$ Most of the waste workers at landfill sites are poor rural migrants shifted to urban settings in search of work and play major role in solid waste recycling in low-income countries. ${ }^{17,18}$ The physical injuries and cuts during the work are the common occupational risks associated with the landfill waste workers at Sisdol. 19,20 The waste workers have less knowledge of occupational health risks and adopt less safety practices at their working site. ${ }^{21} \mathrm{~A}$ study done in dumping sites of Thailand had recommended to incorporate the landfill workers into the formal sector program to reduce work related health hazards. ${ }^{22}$

Personal protective equipment (PPE) acts as a key component for protecting the frontline waste workers against infection. ${ }^{23}$ However, there is very low use of PPE among waste workers in Nepal. ${ }^{24}$ The proper usage of PPE is necessary to understand in order to protect an individual from contamination. ${ }^{25}$ The PPE helps to protect the waste workers from adverse health hazards. ${ }^{20}$ The protection of the waste workers can be achieved by wearing PPE such as mask, gloves, shoes, caps, dress, googles and face shield. ${ }^{26}$ Thus this study intends to assess the knowledge regarding the usage of PPE and challenges faced by waste workers for making this as habit for regular use at Sisdol landfill site.

\section{Methods}

A descriptive cross-sectional study was conducted to collect data from landfill waste workers of Sisdol located in Nuwakot district of Nepal in February 2021. Sisdol is the biggest landfill site of Nepal. A convenience sampling method was used based on the availability of landfill waste workers on that day and their willingness to participate. ${ }^{27}$ The waste workers at Sisdol landfill site were not engaged with any institution and working independently (informally) so there was no record of exact number of waste workers working at the Sisdol landfill site. Only 37 people agreed to participate in our survey conducted at the landfill site. The landfill waste workers giving consent were the part of this survey and had been considered as the sample. The data was collected using the structured questionnaire through face-to-face interview. The questionnaire consisted of the demographic information of landfill waste workers, knowledge of PPE and its usage. Further, a Chi-square test was done to find the association between the variables. Analysis was done using statistical package for social sciences (SPSS) version 20. A consent (Yes/No) was filled up by researchers as most of the respondents were illiterate. Also the landfill waste workers of 16 years and above and those willing to answer the questions (chosen Yes in consent) were only included in this study.

\section{Results}

The demographic status of respondents have been presented in Table 1. A total of 37 waste workers at Sisdol landfill site were studied to determine the knowledge, proper usage and challenges of using PPE at the workplace. Comparatively more females were interested to take part in this study. The study comprised of $65 \%$ female and $35 \%$ male waste workers. The highest percentage $(43 \%)$ of waste workers belong to 27-37 years age group. The least number $(14 \%)$ of waste worker belong to $16-26$ years age group. Around $54 \%$ of the respondents didn't have any formal education. Very less (8\%) respondents had passed the secondary level.

All the respondents (100\%) had heard about PPE and were aware of the benefits of its usage (Table 2). Three major sources of gaining information about PPE were identified during the study. Around $68 \%$ waste workers claimed that they have received information about PPE from media. Also $92 \%$ waste workers had participated in training or any session related to PPE and its usage. Out of $92 \%$ people who had participated in any training or program, around $91 \%$ said that the training on PPE was provided by NGO/INGOs.

Regarding the proper usage of PPE at workplace and challenges, five percent landfill waste workers only used gloves whereas maximum (60\%) waste workers used both mask and gloves (Table 3 ). Majority (64\%) of females declared using both mask and gloves as compared to males (36\%). It was found that most of the waste workers were using the reusable rubber or fabric gloves. Only three percent were using full set of PPE including mask, gloves, shoes, cap, googles, jacket and trouser (Table 3). Maximum (81\%) waste workers have never used full set PPE at their workplace. From gender perspective, out of total respondents, $63 \%$ female had never used full set of PPE compared to male (37\%) (Figure 1). 
The major difficulty in using full set of PPE was uncomfortability $(57 \%)$ during waste segregation (Table 3 ) while $40 \%$ found the PPE to be unsuitable for the summer season. Majority (86\%) were using PPE due to mandatory notice from the local bodies.

The association between sociodemographic components with usage of full set of PPE have been presented in Table 4. Gender, age groups and the education level were found to have no association with the usage of whole set of PPE during the work $(p$-value $>0.05)$. It means usage of whole set of PPE during work is independent with gender, age group and education level.

Table 1: Demographic status of landfill waste workers $(n=37)$

\begin{tabular}{lcc}
\hline Variables & Frequency $(\mathbf{n}=\mathbf{3 7})$ & Percentage (\%) \\
\hline Sex & 13 & 35 \\
Male & 24 & 65 \\
Female & & \\
Age group (yrs) & 5 & 14 \\
$16-26$ & 16 & 43 \\
$27-37$ & 10 & 27 \\
$38-48$ & 6 & 16 \\
$49-59$ & & \\
Education Level & 20 & 54 \\
No formal education & 14 & 38 \\
Primary level & 3 & 8 \\
Secondary level & &
\end{tabular}

Table 2: Knowledge of PPE and source of information $(n=37)$

\begin{tabular}{lccc}
\hline Variables & & Frequency $(\mathbf{n}=\mathbf{3 7})$ & Percentage $\mathbf{( \% )}$ \\
\hline Have heard about PPE & Yes & 37 & 100 \\
& No & 0 & 0 \\
Source of information & Relatives & 3 & 8 \\
& Media & 25 & 68 \\
& Organization & 6 & 16 \\
Participated in training/ & Other & 3 & 8 \\
session on PPE & Yes & 34 & 92 \\
Training provider & No & 3 & 8 \\
& Governmental bodies & 3 & 9 \\
& NGO/INGO & 31 & 91 \\
\hline
\end{tabular}

Table 3: Use of PPE and its challenges $(n=37)$

\begin{tabular}{llcc}
\hline Variables & & Frequency $(\mathbf{n}=\mathbf{3 7})$ & Percentage (\%) \\
\hline \multirow{2}{*}{$\begin{array}{l}\text { Most commonly used } \\
\text { PPE }\end{array}$} & Gloves only & 2 & 5 \\
& Mask and gloves & 22 & 60 \\
& Mask, gloves and shoes & 12 & 32 \\
& Full set (mask, gloves, shoes, cap, & 1 & 3 \\
Usage of full set PPE & googles, coverall set) & & 5 \\
at work & Rometime & 2 & 14 \\
& Rarely & 5 & 81 \\
Difficulty using PPE & Never & 30 & 57 \\
& Not suitable for this season & 21 & 40 \\
& Other & 15 & 3
\end{tabular}




\begin{tabular}{llcc} 
& Own safety & 1 & 3 \\
Reason of using PPE & Fear of COVID & 3 & 8 \\
& Forced by local bodies & 32 & 86 \\
& Other & 1 & 3 \\
Want to continue using & Yes & 34 & 92 \\
PPE & No & 3 & 8 \\
\hline
\end{tabular}

Table 4: Association of different characteristics with usage of whole set of PPE ( $n=37)$

\begin{tabular}{lccccc}
\hline \multirow{2}{*}{ Characteristics } & \multicolumn{3}{c}{ Usage of whole set PPE } & \multirow{2}{*}{ Total $\mathbf{n}(\%)$} & \multirow{2}{*}{ P value } \\
\cline { 2 - 3 } Sex & \multicolumn{1}{c}{ Sometime $\mathbf{n}(\%)$} & Rarely $\mathbf{n}(\%)$ & Never $\mathbf{n}(\%)$ & & \\
Male & $0(0)$ & $2(15)$ & $11(85)$ & $13(35)$ & 0.558 \\
Female & $2(8)$ & $3(13)$ & $19(79)$ & $24(65)$ & \\
Age Group (yrs) & & & & & \\
$16-26$ & $1(20)$ & $1(20)$ & $3(60)$ & $5(14)$ & \\
$27-37$ & 0 & $1(6)$ & $15(94)$ & $16(43)$ & \\
$38-48$ & 0 & $3(30)$ & $7(70)$ & $10(27)$ & \\
$49-59$ & $1(17)$ & 0 & $5(83)$ & $6(16)$ & 0.166 \\
Education level & & & & & \\
No formal education & $1(5)$ & $4(20)$ & $15(75)$ & $20(54)$ & \\
Primary level & $1(7)$ & 0 & $13(93)$ & $14(37)$ & 0.401 \\
Secondary level & 0 & $1(33)$ & $2(67)$ & $3(8)$ & \\
\hline
\end{tabular}

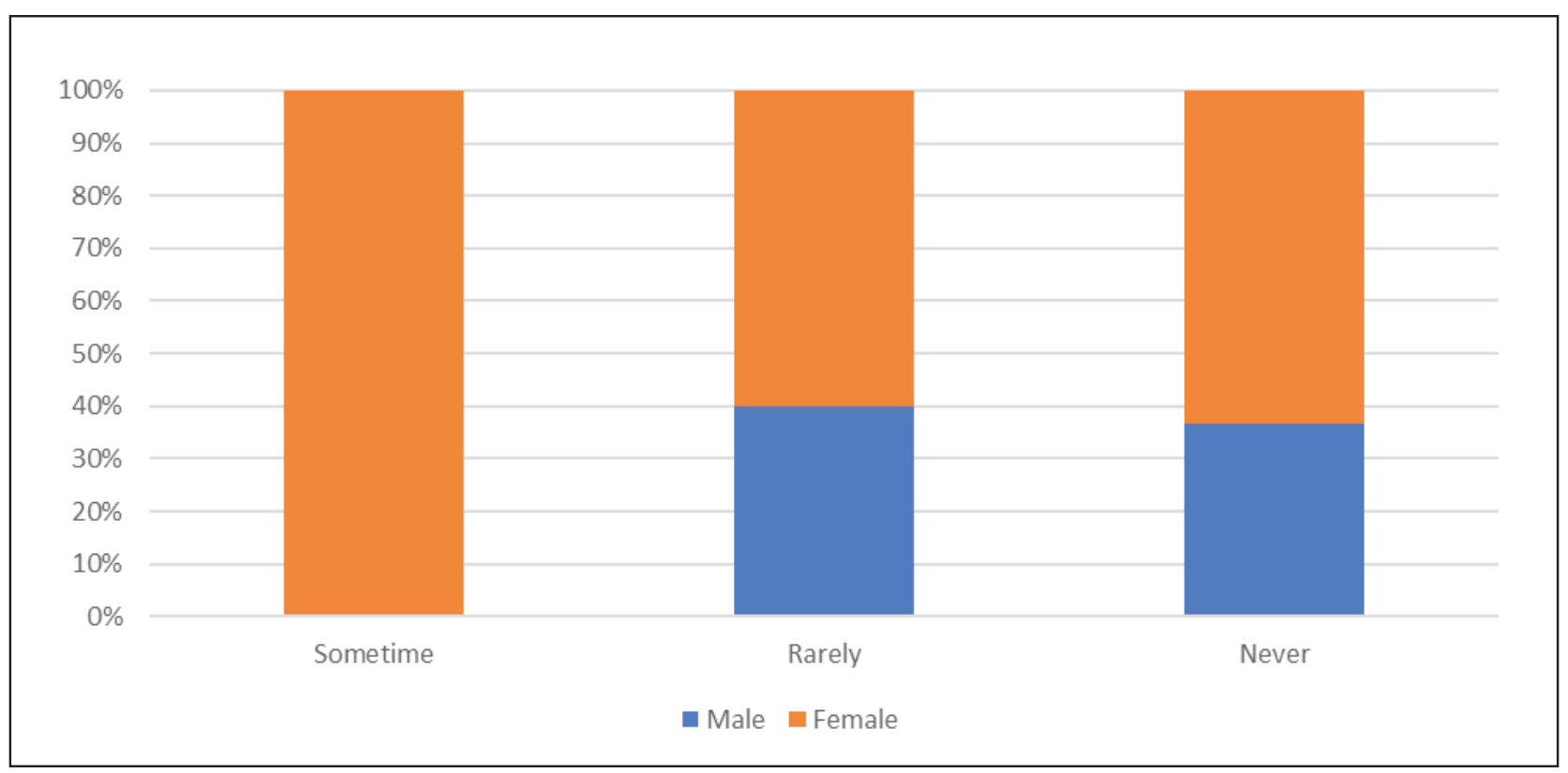

Figure 1: Frequency of using PPE at work place based on gender

\section{Discussion}

The study found that there were more females than males working as the landfill waste workers. Females were interested and ready to share the information regarding their work. It is similar to a study done in Nigeria which found women to be more active even in the household solid waste management. ${ }^{31}$ Also a study about gender concern on the environment revealed that though men had more knowledge about environmental issues but women were found to be more concerned about it. ${ }^{32}$

More than $50 \%$ landfill waste workers had never attended the school for formal education. Though education is considered as the major factor for 
economic and social development of the country, Nepal still needs to work more on improving the educational inclusion for achieving the sustainable development goal four named quality education. ${ }^{33,34}$ The literacy rate of Nepal was $69 \%$ in $2019 .{ }^{35}$ A longitudinal study done in Nepal found gender discrimination in education with parents focusing more on male education..$^{36}$ This may be the reason that all the waste workers don't have multiple employment opportunities due to limited education and skills. ${ }^{37}$ All the landfill workers had heard about PPE and were aware about the benefits of using it during the work. This is similar to an online survey about the precaution and importance of PPE which found that the majority of respondents had enough knowledge about the protective gears..$^{38}$ In another study, around $50 \%$ people claimed that they had received clear and complete information about the use of PPE. ${ }^{39}$ This is less than what was found in the study done in Sisdol landfill site. Around $68 \%$ people said that the media played an important role in disseminating clear information about the benefits of using PPE.

Most of the people (60\%) working at Sisdol landfill site were found using mask and gloves. This was similar to the study where face masks and gloves have been commonly used to protect from respiratory and other infections. ${ }^{40}$ Talking about the usage of full set of PPE during work, $81 \%$ of the landfill waste workers were not using it. A cross-sectional survey of informal waste workers in Kathmandu found about $73 \%$ of workers considered their job as risky, however only $68 \%$ people weren't found using PPE. ${ }^{24}$
Most of the landfill workers (92\%) would like to continue using PPE in the future. This was more compared to Iranian study in 2019 which claimed that only about $56 \%$ respondents had agreed to use full set of PPE in future. ${ }^{41}$ Though the waste workers were aware about the health impact that might cause in absence of PPE, the affordability was also a concern. In most of the cases, the mask and gloves were widely used by waste workers without cleaning it properly. This need to be properly monitored by the landfill officials.

The major difficulty in using full set of PPE was identified as uncomfortability while doing work. This finding aligns with a study done in Egypt in 2020 which found discomfort and lack of knowledge using PPE as the main reasons of not using PPE. ${ }^{42}$

\section{Conclusion}

The usage of PPE among waste workers at Sisdol landfill site in Nepal is not satisfactory. Despite all the landfill waste workers having proper information about PPE, very few respondents have been using full set of PPE while doing work. There is very less number of waste workers who wish to wear full set of PPE. Most of them only like to wear mask and gloves. The majority of the waste workers have discomfort while wearing PPE, yet, want to continue wearing it in future. There is necessity of proper monitoring mechanism to ensure that the landfill waste workers at Sisdol uses full set of PPE to protect from associated occupation health risk.

\section{References}

1. Maharjan MK, Lohani SP. Municipal Solid Waste Management in Nepal: Opportunities and Challenges. $J$ Inst Eng. 2020;15(3):222-6.

2. Asian Development Bank. Solid Waste Management in Nepal. Abstr Pap 7th World Congr . 2005.

3. Dahal Y, Adhikari B. Characterization and Quantification of Municipal Solid Waste in Jeetpur Simara Sub- Metropolitan City, Nepal. Hydro Nepal J Water, Energy Environ. 2018;22:45-7.

4. Ranabhat R. Life Cycle Assessment of Municipal Solid Waste Management System in Kathmandu, Nepal. J Adv Coll Eng Manag. 2016;1:97-106. Available from:https://doi.org/10.3126/jacem. v1i0.14926.

5. Larsson G, Sahlén J, Mårtensson L, Khanal SN. A Case Study of Muniicipal Solid Waste Management in

Nepal Compared to the Situation in the European Union and Sweden. Linnaeus Eco-Tech. 2017. Available from: https://www.diva-portal.org/smash/get/diva2:971265/ FULLTEXT01.pdf.

6. Nepal M, Rai RK, Khadayat MS, Somanathan E. Value of cleaner neighborhoods: Application of hedonic price model in low income context. World Dev. 2020. Available from: https://www.sciencedirect.com/science/article/pii/ S0305750X20300917.

7. Rai RK, Nepal M, Khadayat MS, Bhardwaj B. Improving municipal solid waste collection services in developing countries: A case of Bharatpur Metropolitan City, Nepal. Sustainability. 2019; 11(11):3010.

8. Dhungana AR. Determinants of Willingness to Pay for Improved Solid Waste Management System in Lekhnath, Kaski, Nepal. Janapriya J Interdiscip Stud. 2018; 6:1-16. Available from:https://doi.org/10.3126/jjis. v6i0.19305. 
9. ADB. Solid Waste Management in Nepal: Current Status and Policy Recommendations. 2013. Available from: https://www.adb.org/publications/ solid-waste-management-nepal-current-status-andpolicy-recommendations.

10. Khanal A, Giri S. Possibility of Community Based Solid Waste Management Project in Chuchepati, Kathmandu. J Basic Appl Eng Res. 2016;3(1):6-8.

11. Pathak DR, Mainali B. Status and opportunities for materials recovery from municipal solid waste in Kathmandu Valley, Nepal. Environmental Science and Engineering. 2019. Available from: https://link.springer.com/ chapter/10.1007/978-981-13-2221-1_46.

12. Kaza S, Yao LC, Bhada-Tata P, Van Woerden F. What a Waste 2.0: A Global Snapshot of Solid Waste Management to 2050. 2018.

Available from: https://openknowledge. worldbank.org/handle/10986/30317.

13. Lohani SP, Keitsch M, Shakya S, Fulford D. Waste to energy in Kathmandu Nepal-A way toward achieving sustainable development goals. Sustainable Development. 2021. Available from: https:// onlinelibrary.wiley.com/doi/epdf/10.1002/sd.2183.

14. Dangi MB, Cohen RRH, Urynowicz MA, Poudyal KN. Report: Searching for a way to sustainability: Technical and policy analyses of solid waste issues in Kathmandu. Waste Manag Res. 2009;27(3):295301.

15. Abdou MHM. Health impacts on workers in landfill in Jeddah City, Saudi Arabia. J Egypt Public Health Assoc. 2007;82(3):319-29.

16. Kathpalia D, Zafar M, Alappat BJ. Occupational hazards of working at landfill sites. Indian J Environ Prot. 2002

17. Rouse JR. Seeking common ground for people: Livelihoods, governance and waste. Habitat Int. 2006;30(4):741-53.

18. Khanal A. Livelihood Status of Itinerant Waste Buyers in Kathmandu.Appl Ecol Environ Sci. 2021;9(5):53740. Available from: http://pubs.sciepub.com/ aees/9/5/4/index.html.

19. Sapkota S, Lee A, Karki J, Makai P, Adhikari S, Chaudhuri N, et al. Risks and risk mitigation in wastework: A qualitative study of informal waste workers in Nepal. Public Heal Pract. 2020. Available from: https://www.sciencedirect.com/science/article/pii/ S2666535220300276.

20. Wassiem A, Zaki GR, Charl F, El-Gazzar R. Biochemical changes among municipal solid waste sorting workers: implications for personal protective equipment availability and use. Int $\mathrm{J}$ Occup Saf Ergon. 2019. Available from: https://pubmed.ncbi. nlm.nih.gov/31570081.
21. Asibey MO, Amponsah O, Yeboah V. Solid waste management in informal urban neighbourhoods. Occupational safety and health practices among tricycle operators in Kumasi, Ghana. Int J Environ Health Res. 2019. Available from: https://www. tandfonline.com/doi/abs/10.1080/09603123.2019.15 69211.

22. Thirarattanasunthon $P$, Siriwong $W$, Robson $M$, Borjan M. Health risk reduction behaviors model for scavengers exposed to solid waste in municipal dump sites in Nakhon Ratchasima Province, Thailand. Risk Manag Healthc Policy. 2012.

Available from: https://pubmed.ncbi. nlm.nih.gov/22969307.

23. Ndejjo R, Musinguzi G, Yu X, Buregyeya E, Musoke D, Wang JS, et al. Occupational Health Hazards among Healthcare Workers in Kampala, Uganda. J Environ Public Health. 2015. Available from: https:// pubmed.ncbi.nlm.nih.gov/25802531.

24. Black M, Karki J, Lee ACK, Makai P, Baral YR, Kritsotakis El, et al. The health risks of informal waste workers in the Kathmandu Valley: a cross-sectional survey. Public Health. 2019; 166:10-8. Available from: https://www.sciencedirect.com/science/article/ abs/pii/S0033350618303159.

25. Reddy SC, Valderrama AL, Kuhar DT. Improving the Use of Personal Protective Equipment: Applying Lessons Learned. Clin Infect Dis. 2019; 69(3):16570.

26. Martin WF, Lippitt JM,Webb PJ. Hazardous Waste Handbook. 2000. Available from: https://www. elsevier.com/books/hazardous-waste-handbook/ lippitt/978-0-7506-7135-4.

27. Etikan I. Comparison of Convenience Sampling and Purposive Sampling. Am J Theor Appl Stat. 2016; 5(1):1-4.

28. Jenkins DG, Quintana-Ascencio PF. A solution to minimum sample size for regressions. PLoS One. 2020. Available from: https://journals.plos.org/ plosone/article?id=10.1371/journal. pone. 0229345 .

29. Delice $A$. The sampling issues in quantitative research. Educ Sci Theory Pract. 2001; 10(4):200118.

30. Roscoe JT. Fundamental Research Statistics for The Behavioural Sciences (2nd Edition). Holt Rinehart \& Winston, New York. 1975.

31. Gani BA, Chiroma A, Bukar A, Gana A. Women and Solid Waste Sgregation in Bauchi Nigeria. J Environ Earth Sci. 2012; 2(8). Available from: https://www. iiste.org/Journals/index.php/JEES/article/view/2739.

32. Schahn J, Holzer E. Studies of individual environmental concern: The Role of Knowledge, Gender, and Background Variables. Environ Behav. 1990; 22(6). Available from: https://journals. sagepub.com/doi/10.1177/0013916590226003. 
33. Upadhyay JP. Higher Education in Nepal. Pravaha. 2018;24(1):96-108.

34. Daly A, Parker S, Sherpa S, Regmi U. Federalisation and education in Nepal: contemporary reflections on working through change. Educ 3-13. 2020;48(2):16373.

35. Duvey D. Comparison of Socio Economic Development of Tarai and Nepal. Res Nepal J Dev Stud. 2020;3(1):67-76.

36. Khanal S. Gender discrimination in education expenditure in Nepal: Evidence from living standards surveys. Asian Dev Rev. 2018;35(1):155-74.

37. Dias SM. Statistics on Waste Pickers in Brazil. Women Informal Employ Glob Organ. 2011.Available from: https://www.wiego.org/publications/statisticswaste-pickers-brazil.

38. Preethi G, Abilasha R, Premavathy D. Precautions and importance of ppe-assessment of knowledge among dental health care workers-a questionnaire based study. Int J Res Pharm Sci. 2020:11(3):1791-8.

39. Savoia E, Argentini G, Gori D, Neri E, Piltch-Loeb R, Fantini MP. Factors associated with access and use of PPE during COVID-19: A cross-sectional study of Italian physicians. PLoS One. 2020;15(10). Available from: https://pubmed.ncbi.nlm.nih.gov/33044978

40. Chughtai AA, Khan W. Use of personal protective equipment to protect against respiratory infections in Pakistan: A systematic review. J Infect Public Health. 2020; 12(4):522-7.

41. Abdollahzadeh G, Sharifzadeh MS. Predicting farmers' intention to use PPE for preventing pesticide adverse effects: An examination of the Health Belief Model (HBM). J Saudi Soc Agric Sci. 2021;20(1):40-7.

42. Sehsah R, El-Gilany $A H$, Ibrahim AM. Personal protective equipment (PPE) use and its relation to accidents among construction workers. Med del Lav. 2020;111(4):285-95. 